AperTO - Archivio Istituzionale Open Access dell'Università di Torino

\title{
Developments in real-time radon monitoring at Stromboli volcano
}

\section{This is the author's manuscript}

Original Citation:

\section{Availability:}

This version is available http://hdl.handle.net/2318/118811

since

Published version:

DOI:10.1016/j.jenvrad.2011.10.006

Terms of use:

Open Access

Anyone can freely access the full text of works made available as "Open Access". Works made available under a Creative Commons license can be used according to the terms and conditions of said license. Use of all other works requires consent of the right holder (author or publisher) if not exempted from copyright protection by the applicable law. 


\section{(3) \\ UNIVERSITÀ DEGLI STUDI DI TORINO}

This Accepted Author Manuscript (AAM) is copyrighted and published by Elsevier. It is posted here by agreement between Elsevier and the University of Turin. Changes resulting from the publishing process - such as editing, corrections, structural formatting, and other quality control mechanisms - may not be reflected in this version of the text. The definitive version of the text was subsequently published as

Laiolo M., Cigolini C., Coppola D., Piscopo D. (2012). Developments in real-time radon monitoring at Stromboli volcano. JOURNAL OF ENVIRONMENTAL RADIOACTIVITY, vol. 105, p. 21-29, ISSN: 0265-931X

You may download, copy and otherwise use the AAM for non-commercial purposes provided that your license is limited by the following restrictions:

(1) You may use this AAM for non-commercial purposes only under the terms of the CC-BY-NC-ND license.

(2) The integrity of the work and identification of the author, copyright owner, and publisher must be preserved in any copy.

(3) You must attribute this AAM in the following format: Creative Commons BY-NC-ND license (http://creativecommons.org/licenses/by-nc-nd/4.0/deed.en), [+ Digital Object Identifier published journal article on Elsevier's ScienceDirect ${ }^{\circledR}$ platform]

doi: 10.1016/j.jenvrad.2011.10.006

http://www.sciencedirect.com/science/article/pii/S0265931X11002451 


\title{
Developments in real-time radon monitoring at Stromboli volcano
}

\author{
Laiolo M. ${ }^{1}$, Cigolini C. ${ }^{1,2}$, Coppola D. ${ }^{1} \&$ Piscopo D. ${ }^{1}$ \\ ${ }^{1}$ - Dipartimento di Scienze Mineralogiche e Petrologiche, Università di Torino, Via Valperga Caluso 35, Torino \\ 2 - Centro Interdipartimentale sui Rischi Naturali ("NatRisk")
}

\begin{abstract}
We present the results of one year of continuous radon monitoring at Stromboli volcano collected at two automated real-time stations. These were deployed on the NE flank (at $520 \mathrm{~m}$ a.s.1.) and within the summit area (900 m a.s.1.). Higher daily emissions at the lower station approached 4,200 Bq/ $\mathrm{m}^{3}$, with bulk averages around $1,800( \pm 980) \mathrm{Bq} / \mathrm{m}^{3}$; whereas the summit station reached peak values of $23,000 \mathrm{~Bq} / \mathrm{m}^{3}$ and bulk averages of $12,500 \mathrm{~Bq} / \mathrm{m}^{3}( \pm 4,000)$. Negative correlations are observed between radon emissions, soil temperature and, to a lesser extent, atmospheric pressure. In contrast, an increases in radon concentrations were observed during periods of higher rainfall conditions. Therefore, trends in radon concentrations may be decoupled from those of other geochemical parameters $\left(\mathrm{CO}_{2}\right.$ fluxes and $\mathrm{CO}_{2} / \mathrm{SO}_{2}$ plume ratios) during periods of heavy to moderate rainfalls. Multiple Linear Regression statistics (including the effects of soil temperature, atmospheric pressure and tidal forces) led us to compute the residuals given by the difference of measured and calculated ${ }^{222} \mathrm{Rn}$ concentrations. The cross-check between the daily measured radon activities and the absolute variations in radon residuals, for the data collected at the summit station, give us the opportunity to suggest a methodological approach that can be used in the attempt of predicting some major changes in volcanic activity.
\end{abstract}

\section{Introduction}

It is generally accepted that decoding anomalous radon emissions, together with those of other geochemical and geophysical parameters, may better assess volcanic alert procedures and eruption and earthquake forecasting. Radon is an alpha emitting radioactive gas produced from the decay of 
uranium and thorium bearing rocks, soils and magmas. It plays a crucial role in the outgassing process of the earth and its spatial and temporal variations have been regarded as precursors of earthquakes and volcanic eruptions. Earth scientists use the isotope ${ }^{222} \mathrm{Rn}$ (with a half life of 3.82 days) as a "geochemical tracer", since its anomalies have been observed before, during and after the onset of regional seismic events (e.g., Scholtz et al., 1973; Fleischer and Mogro-Campero, 1985; Igarashi et al., 1995; Planicić et al., 2004; Pulinets et al., 2009; Cigolini, 2010). These issues have been challenged by Wyss $(1991 ; 1997)$ and Wakita (1996) who discuss the limits identifying earthquake precursors solely based on radon monitoring. Moreover, variations in radon emissions have been associated with changes in volcanic activity and volcanically-related earthquakes (Cox, 1980; Thomas et al., 1986). At Somma-Vesuvius (Italy), Cigolini et al. (2001) used a network for radon monitoring to discriminate radon anomalies related to regional earthquakes from those associated to local volcanic seismicity. In addition, Burton et al. (2004) inferred, on the basis of radon measurements, the geometry of a hidden fault during the seismic crises of October, 2002 at Mount Etna. More recently, Cigolini et al. (2007) were able to detect earthquake-volcano interactions at Stromboli in terms of a time-delay of radon anomalies in respect to the onset of major seismic events within the southern Tyrrhenian region.

High radon emissions across active faults have the capability of generating ionization of the nearground layer of the atmosphere since its decay products may become clusters for water condensation and local temperature anomalies (due to the release of the latent heat from evaporation), eventually leading to thermal anomalies that may precede earthquakes (Ouzounov and Freund, 2004; Pulinets et al., 2009). However, radon anomalies have also been regarded as precursors to volcanic eruptions (e.g., Chirkov, 1975; Connors et al., 1996; Alparone et al., 2005; Cigolini et al., 2005; Neri et al., 2006; Giammanco et. Al., 2007). Su and Huh (2002) recorded increased contents of ${ }^{210} \mathrm{Po}$ (a daughter product of ${ }^{222} \mathrm{Rn}$ ) deposited by the plume of Mayon volcano prior to its last eruption. 
Diffuse and concentrated degassing in volcanic areas may release high amount of gas and its monitoring can be helpful in volcano surveillance (e.g., Allard et al., 1991; Viveiros et al., 2008). In recent years this approach has been undertaken at several volcanoes (Varley et al., 2001; Carapezza et al., 2004; Williams-Jones et al., 2000; Hernandez et al., 2004; Neri et al., 2006). Radon transport towards the surface occurs preferentially along faults or cracks of the substrate, and it is controlled by the physical properties of the underlying rocks (e.g. porosity and permeability). Radon can migrate throughout soil pores not only by gas-phase diffusion but also by convection and advection. According to Gauthier et al. (1999), in volcanic areas, the radon gas is essentially carried by water and carbon dioxide. Environmental parameters are critical in modulating radon emissions (e.g., Mogro-Campero and Fleischer, 1977; Pinault and Baurbon, 1996; Pérez et al., 2007; among others). In particular, Zimmer and Erzinger (2003) found a positive correlation between radon concentrations, atmospheric pressure and water contents during their monitoring of high temperature fumaroles at Merapi Volcano. Moreover, the effects of environmental parameters on volcano degassing led Viveiros et al. (2008) and Carapezza et al. (2009) to analyze $\mathrm{CO}_{2}$ fluxes by taking into account the effects of environmental parameters on the $\mathrm{CO}_{2}$ signals. However, radon concentrations can be diluted by major fluxes of $\mathrm{CO}_{2}$ and vapor water (e.g., Giammanco et al., 2007; 2009; Siniscalchi et al., 2010).

The use of automatic alpha particles detectors allow us to better decode the interplay among seismic signals and others geochemical parameters that may precede the onset of volcanic eruptions (Ripepe et al., 2005; Allard et al., 2008).

Real-time radon measurements strategically increase the potential role of radon in volcano monitoring since the data are automatically transferred and previously elaborated, filtering the effects of environmental parameters on radon degassing (Cigolini et al., 2009). Thus, systematic time series analysis and signal processing give us the opportunity to better track degassing at active volcanoes and substantially contribute to refine surveillance strategies and alert procedures. 
However, the applications of these methods could also be easily applied in monitoring the relationships between radon and seismicity in tectonically active areas.

In this framework, we analyze the radon signals by means of Multiple Linear Regression analysis, in the light of environmental parameters (soil temperature and atmospheric pressure) and tidal forces, that may be used to identify a correlation between radon emissions and other key geochemical parameters. We finally discuss how our methodological approach and our results may contribute to improve geochemical monitoring and, consequently, volcano surveillance.

\section{Stromboli Volcano}

Stromboli is an active stratovolcano located in the southern Tyrrhenian region, the north-eastern island of the Aeolian arc (Fig. 1). The volcano rises $924 \mathrm{~m}$ above sea level but the base of the cone reaches a depth of about 2,000 m below sea level. The volcanic edifice has grown on a NE strikeslip fault known as the Stromboli-Panarea alignment. This structure is connected to the NNW trending Tindari-Letojanni faulting system: a major structure that propagates though Eastern Sicily to the Ionian sea (e.g., De Astis et al., 2003; Acocella et al., 2009).

Stromboli volcano shows a rather unique and persistent open-system activity with moderate eruptions of ash, lapilli, scoriae and bombs from summit vents (e.g., Rosi et al., 2000). This mild and persistent activity may be associated with major explosions with ejection of blocks and bombs that affect the summit area and the surrounding sectors. The onset of a major eruptive period occurs with lava effusions eventually leading to high risk paroxysmal explosions. These are characterized by the projection of ash, pumices, bombs and blocks of several tonnes that may reach the villages of Stromboli and Ginostra (e.g., Barberi et al., 1993).

The onset and the evolution of the major eruptive period of 2002-2003 further attracted the scientific interest on this volcano. Lava effusion from the summit vents started on December 28, 2002 and was followed, on December 30, 2002, by a composite slump down the "Sciara del Fuoco" (a horse-shoe shaped scarp open northeast inherited from a multiple flank collapse, see Tibaldi et al. 
(2009) and references therein), triggering a tsunamis that damaged parts of the Stromboli village and reached the coasts of Sicily and Calabria. In the following days the lava effusion continued, summit vents were dismissed and the typical strombolian activity temporarily ceased until the end of July 2003. Lava outflow was accompanied, on April 5, 2003, by the onset of a paroxysmal explosion with the ejection ash, abundant pumices bombs and lithic blocks (Bonaccorso et al., 2003; Ripepe et al., 2005; Calvari et al., 2005). The geochemical anomalies that preceded these two eruptive events were discussed by Carapezza et al. (2004) and Cigolini et al (2005). The relationships among geophysical signals (VLP events basically related to the Stromboli explosive activity), thermal anomalies and $\mathrm{SO}_{2}$ plume degassing were discussed by Ripepe et al. (2005).

The most recent effusive event, that replaced the mild strombolian activity, started on February 27, 2007 and persisted until April 2, 2007. A new and violent paroxysmal explosion occurred on March 15,2007 . with the ejection of ash, pumices bombs and projectiles that damaged two houses in the village of Ginostra. The explosion was preceded by a marked increase in volcanic seismicity accompanied and followed by a progressive vertical collapse of the crater area (Barberi et al., 2008; Neri and Lanzafame, 2008). A transitional phase, characterized by moderate seismic and infrasonic activity (and absence of explosions at the summit vents) persisted until the end of June-beginning of July, 2007 when the mild strombolian activity finally resumed. Geochemical data on precursory signals for this eruption were provided by Rizzo et al. (2009) and Aiuppa et al. (2009).

Currently activity is typically strombolian but major explosions (intermediate between paroxysmal explosions and the typical mild explosive activity) have been more frequent when compared to the earlier and recent eruptive history. Current scientific goals are thus focused in decoding the precursory signals associated with onset of these explosive events that may threaten the life of hikers and scientists occasionally exposed in the summit area.

During our monitoring (May 2008 - May 2009), Stromboli was essentially characterized by its typical Strombolian activity, and a total of 3 major explosions explosions stronger then the ordinary activity with an overpressure at the vents $>2$ bar (measured according to the methods of Ripepe et 
al., 2007). A minor lava overflow from the summit crater occurred on March 29, 2009. The mild strombolian activity substantially increased during March-May 2009, with a marked increase in the explosive rate at the summit vents.

\section{Radon measurements and techniques}

Earlier radon measurements, starting May 2002, were performed by track-etch detectors (LR115, finely calibrated according to Bonetti et al. (1991) and E-PERM ${ }^{\circledR}$ electretes (Kotrappa et al., 1993) at 25 selected sites located on the major structural features of the volcano. Detectors were placed in pipe-like samplers $(1.20 \mathrm{~m}$ long with a diameter of $12 \mathrm{~cm})$ inserted into soil at an approximate depth of about $60 \mathrm{~cm}$. Repeated periodic surveys in the following years allowed us to identify the sites of more efficient degassing. Two of these sites were chosen to install real-time radon stations. The first one, named Liscione (LSC in Fig. 1a, a locality in northeastern sector at $520 \mathrm{~m}$ a.s.1.), is located between the $\mathrm{N} 40^{\circ} \mathrm{E}$ and $\mathrm{N} 60^{\circ} \mathrm{E}$ fracture zones (the main structural alignments of the island). The station lays on top of a 10-15 m deposit consisting of fine to coarse ash that covers the Cannestrà lava flow (Fig. 1a) that was erupted from a N40 ${ }^{\circ} \mathrm{E}$ fracture $13-6$ ky before present (Gillot \& Keller, 1993; Keller et al., 1993; Finizola et al., 2002; Tibaldi, 2001; Tibaldi et al., 2009).

The second station, named Pizzo (PZZ in Fig. 1 at $900 \mathrm{~m}$ of altitude a.s.1.) is located in the summit area above the $\mathrm{N} 40^{\circ} \mathrm{E}$ fracture zone parallel to craters alignment, at a distance of about $150 \mathrm{~m}$ from the active fumaroles (Fig. 1b). In addition, several automated stations were periodically deployed at selected sites where data could be seasonally downloaded by means of a portable PC.

The assemblage and set ups for real time stations were presented in an earlier paper (Cigolini et al., 2009); here we will briefly recall the main features and then focus our attention on spectral signatures and real-time measurements.

A single station for real-time measurements consisted of an electronic radon detector (DOSEman made by Sarad GmbH, Dresden, Germany) integrated by an electronic board that transfered the 
output signal to a radio modem. These units were assembled and stored in a in a polycarbonate case (permeable to radon) positioned within a PVC box (open downward). This box was inserted into the soil down to a depth of $\sim 1 \mathrm{~m}$. The space inside the box was occupied by "free soil air" and the gas flux into the atmosphere was promoted by a tube positioned at the top of the box. The tube was interconnected with a cylindrical "expansion reservoir" that attenuated the effects of atmospheric perturbations.

Collected data were sent, through a directional antenna, to a receiving station at the volcano observatory. The sampling time for radon measurements and acquisition of environmental parameters (site soil temperature and atmospheric pressure) was set at 15 minutes. Data were systematically trasferred, processed and visualized as a time series that could be easily checked via web.

Streil et al. (2002) and Gründel and Postendörfer (2003) reported the technical features of the electronic radon dosimeter. In DOSEman, radon diffuses passively through a leather membrane into a measurement chamber (cylindrical in shape and $12 \mathrm{~cm}^{3}$ in volume) where the charged particles concentrate onto a Si-doped semiconductor detector and are counted by means of an automated alpha spectrometer. Detected particles' decays are stored and processed by means of a multichannel analyzer that splits the counts into energetic domains or Regions of Interest (ROIs), and generates the spectrum of the radon gas. The sensitivity of the instrument is between $10 \mathrm{~Bq} / \mathrm{m}^{3}$ to 4 millions of $\mathrm{Bq} / \mathrm{m}^{3}$. The DOSEman detects alpha-particle decays within an energy window between 4500 and $10000 \mathrm{keV}$ that includes the peaks of ${ }^{222} \mathrm{Rn}$ itself plus the peaks of the daughter products $\left({ }^{218} \mathrm{Po}\right.$ and ${ }^{214} \mathrm{Po}$; at 6200 and $8000 \mathrm{keV}$, respectively) as well as the energy interval represented by ${ }^{220} \mathrm{Rn}$ (thoron, due to the decay of the ${ }^{232} \mathrm{Th}$ chain) and ${ }^{212} \mathrm{Po}$. The total decays measured for each radionuclides are automatically processed by an internal multichannel analyzer and the counts are arranged in five adjusted ROIs (regions of interest) (Gründel and Postendörfer;2003). According to Gründel and Postendörfer (2003; p. 290) the counts for ${ }^{214}$ Po need to be corrected, since the higher side of the ${ }^{220} \mathrm{Rn}$ spectrum overlaps the ${ }^{214} \mathrm{Po}$ peak. Their calibrations suggest that $7.5 \%$ of the 
counts are ascribed to thoron. Radon concentration is expressed in $\mathrm{Bq} / \mathrm{m}^{3}$ and is computed from the total counts of specific ROIs, acquired during a given sample-time, by introducing an instrumental calibration factor $\left(\mathrm{C}_{\mathrm{f}_{\mathrm{i}}}\right)$ related to the volume of the measurement chamber (Gründel and Postendörfer, 2003):

$$
\mathrm{C}_{\mathrm{i}}\left[\mathrm{Bq} / \mathrm{m}^{3}\right]=\left(\mathrm{C}_{\mathrm{f}_{\mathrm{i}}} / \mathrm{Cts} *\left(1 / \mathrm{t}_{\mathrm{s}}\right)\right) * 1000
$$

where Cts are the counts, $t_{s}$ is the sample time (in minutes) and 1000 is the conversion factor from $\mathrm{kBq} / \mathrm{m}^{3}$ to $\mathrm{Bq} / \mathrm{m}^{3}$. Radon can be computed in fast mode taking into account the counts for ${ }^{222} \mathrm{Rn}$ and ${ }^{218} \mathrm{Po}$ (sum of the ROI1 and ROI2 counts), and in slow mode if we include the counts of ${ }^{214} \mathrm{Po}$ (sum of the ROI1, ROI2 and ROI4 counts) as well. A summary of calibration factors is reported by Gründel and Postendörfer (2003). In our analysis we preferred to use the fast mode option because ${ }^{214}$ Po tends to cluster with aerosol particles. In addition, we did not have to take into account thoron interferences on the ${ }^{214}$ Po peaks. In Table 1, we present the count values for each ROI as well as the calibration factors used for fast and slow mode at both stations. The average error at radon concentration of $1000 \mathrm{~Bq} / \mathrm{m}^{3}$ was observed to be $\pm 25 \%$, drastically decreasing at higher emissions (Streil et al., 2002).

In Fig. 2 we report the spectral distribution of the different isotopes of the radon progeny detected at the two real-time stations during a year long monitoring, together with the daily counts for each isotope (subdivided into Region of Interest, ROIs) cumulated for the whole year. In general, it can be observed that the counts at the PZZ station were substantially higher, likely due to the fact it was located near the summit fracture within a sector of concentrated degassing. In addition, the overall shape of the left side of both spectra (namely ROI 1) was quite similar in shape, whereas the peaks of ${ }^{218} \mathrm{Po}$ and ${ }^{214} \mathrm{Po}$ were definitely sharper at the PZZ station. This may reflect minor differences in the experimental calibration of single detectors. However, it was possible that differences in gas 
ascent rates, as well variations in porosities and permeabilities of the underlying rock-soil units may

have affected spectral shapes. However, the uncorrected counts of ${ }^{220} \mathrm{Rn}$ (obtained by detecting the peak of the daughter isotope ${ }^{216} \mathrm{Po}$ ) were considerably lower than those of the other short-lived isotopes.

\section{One year of real-time radon monitoring}

The time series for daily averages in radon concentrations at the LSC and PZZ stations from May 1, 2008 to May 31, 2009 are reported in Fig. 3 and Fig. 4, together with those of soil temperatures and atmospheric pressure. The time series for the data collected at the LSC station (Fig. 3) showed that higher daily emissions approached $4200 \mathrm{~Bq} / \mathrm{m}^{3}$, whereas the average, calculated on the entire dataset, was $1800 \mathrm{~Bq} / \mathrm{m}^{3}$ ( \pm 980 ) (see Table 2). It can be observed that the relative maximum in the activity of radon was reached in the second half of November 2008. Although there was an overall similarity with the LSC trend, daily average concentrations recorded at PZZ were considerably higher and reached $23000 \mathrm{~Bq} / \mathrm{m}^{3}$ during the end of November 2008 (Fig. 4). In this case, the average concentration was $12500 \mathrm{~Bq} / \mathrm{m}^{3}$ ( \pm 4000$)$. The time series for soil temperatures at the LSC station basically reflected seasonal variations, these also affected the yearly trend at the PZZ station but this time series was also affected by the higher local temperature gradient since the detector was placed at about $150 \mathrm{~m}$ from the active fumaroles of the summit. Therefore fluctuations in this parameter at PZZ were more evident with a more discontinuous trendthe trend was more discontinuous. However, a cross-correlation between temperature and radon emissions showed a negative correlation for both measurement sites, and the PZZ station exhibited a higher correlation (Fig. 5 and Table 2). In general, the trend for radon activity showed that radon was higher during the fall and winter and it substantially decreased during late spring and summer (with relative minima recorded during June-August 2008). This is consistent with the observations of MogroCampero and Fleischer (1977) who first ascribed this phenomenon to be the result of the summer time heating of the earth's surface that would cause a seasonal inversion in the near surface 
temperature gradient. This would create a barrier to the upward migration of radon since the efficiency of hydrothermal convection at the surface will be drastically reduced (Cigolini et al., 2001; 2009).

The relationship with atmospheric pressure was rather cryptic. In few cases there seemed to be a delay time in the response of radon to variations in atmospheric pressure (increasing and/or decreasing trends, particularly during those months that follow seasonal changes). However, if signals were analyzed strictly in terms of correlation coefficient, we obviously come to the conclusion that there was only a minor negative correlation between the in-soil radon signal and atmospheric pressure (Fig. 3 and 4, Tab. 2).

In order to have a more reliable radon signal and following Viveiros et al. (2008), Pérez et al. (2007), Carapezza et al. (2008), a Multiple Linear Regression Analysis was performed on the raw data in order to minimized the effects of environmental parameters (soil temperature and air pressure) and tidal forces. Multiple linear regression analysis was carried out to predict the values of a dependent variable $(\mathrm{Y})$ given a set or predictor variables $\left(\mathrm{x}_{1}, \mathrm{x}_{2}, \ldots, \mathrm{x}_{\mathrm{n}}\right)$. We used the relationship between the dependent variable $\left(\mathrm{Y}_{\text {calc }}\right)$ and the explanatory variables according to:

$$
\mathrm{Y}_{\text {calc }}=\mathrm{Y}_{0}+\mathrm{b}_{1} \mathrm{X}_{1}+\mathrm{b}_{2} \mathrm{X}_{2}+\ldots+\mathrm{b}_{\mathrm{n}} \mathrm{X}_{\mathrm{n}}
$$

the $Y_{0}$ is the intercept, $X_{n}$ the acquired variables and $b_{n}$ the regression coefficients (e.g., Hernandez et al., 2004). Thus, we used the above analysis to find and then remove (to calculate residuals) the contribution of the given environmental parameters that may affect radon concentrations (at both real time stations).

In a recent paper (Cigolini et al., 2009), we showed that tidal forces actively modulate radon degassing at Stromboli volcano, supporting the earlier findings of Barnet et al. (1997). Therefore, in analyzing our data we considered the normalized sinusoidal signal constructed from the values of Ephemerids at Stromboli (composed by declination, distance and moon phases). Following this procedure, residuals were obtained by the difference between measured and calculated ${ }^{222} \mathrm{Rn}$ concentrations (Figs. 6 and 7, respectively). The results give light on the role played by 
environmental parameters in modulating ${ }^{222} \mathrm{Rn}$ soil concentrations and, consequently, can be used in filtering the radon signal.

\section{Radon and other geochemical parameters}

In order to have a more comprehensive overview for the behavior of radon during Strombolian activity, we compared the radon signal recorded at the summit station with other geochemical and geophysical data. We must recall that during the period of analysis, (May 2008-May 2009) Stromboli was more active in fall/winter, with the ordinary activity punctuated by a summit lava flow (March 29, 2009; indicating the conduit was completely filled with magma) and 3 stronger explosions (December 6 and 17, 2008, and May 3, 2009) with the first explosion being the strongest event recorded since the onset of the last 2 paroxysms (April 5, 2003 and March 15, 2007).

The recorded time series were compared with the weekly data for radon concentrations and the cumulative curve for daily rain-falls. This analysis is focussed on the summit stations where all the measured parameters are available (Fig. 8). An increasing trend in gaseous emissions, for radon and $\mathrm{CO}_{2}$ and to a lesser extent $\mathrm{CO}_{2} / \mathrm{SO}_{2}$ ratios, was recorded from early August to September 2008. Since then, the cited parameters fluctuated and were partly decoupled until they returned to an increasing trend from the end of November to the end of 2008. In particular, anomalous peaks preceded the sequence of the major explosion of December 6 2008, with vent overpressure of 9 bar. While the trends in $\mathrm{CO}_{2}$ and $\mathrm{CO}_{2} / \mathrm{SO}_{2}$ fluctuate and decreased during the following months, radon is growing until March 2009 and then decreases with other parameters as well. This anomalous radon increase during late winter-early spring seemed to be related to the marked increase in rain waters (see the cumulative curve reported in Fig. 8). This is consistent with the observations of Perrier et al. (2009) who recorded a positive response of radon concentrations (somehow delayed in time) to rainfalls. Moreover, it is well known that higher water contents in soils are capable of increasing the radon emanation factor; at the same time, increase in soil humidity drastically enhances its mobility through the soil pores (Nazaroff et., 1992). However, radon migration may be reduced in moist soil 
because radon is soluble in the pore water, but this will contribute to increase its background concentration at the measurement site. At Stromboli, this process was associated with general decrease in soil temperatures accompanied by a marked increase in radon emissions. In addition, meteoric waters percolating though the fracture network will dilute the carbon-dioxide concentrations, thus momentarily reducing $\mathrm{CO} 2$ fluxes through the hydrothermal system of the summit (Finizola et al., 2003). Finally, we attempted to correlate the variations in radon concentrations with two major explosions that occurred during our monitoring. These occurred on December 6, 2008 (with a vent overpressure $\mathrm{P}_{\mathrm{ov}}=9$ bar measured by Laboratorio di Geofisica Sperimentale of the University of Florence, cfr. Ripepe et al., 2007), and May 3, $2009\left(\mathrm{P}_{\mathrm{ov}}=5.2\right.$ bar). The first was the stronger major explosion recorded at Stromboli since the end of 2002. Only paroxysmal explosions develop higher overpressures (e.g., Harris and Ripepe, 2007). During our recent monitoring, a minor lava overflow occurred on March 29, 2009, from the NE crater.

During mild Strombolian activity, explosions are essentially below 1-2 bar, and only occasionally may reach higher overpressures. We thus emphasize that major explosions are characterized by higher vent overpressure. Therefore, we expect that the most violent major explosions (with $\mathrm{P}_{\mathrm{ov}}>>5$ bar) could eventually provide some precursory signals. In all other cases, it would be impossible to detect anomalies since most of major explosions are only somehow higher those occurring during the typical mild activity.

In Fig. 9 we report the absolute variations of the daily residuals obtained by Multiple Linear Regression statistics compared with the raw data of radon daily emissions (at the Pizzo station, PZZ) and the onset times for the above events. It must be emphasized that our previous measurements (Cigolini et al., 2005) indicated that prior to the onset of lava effusion (on December 28, 2002) and the paroxysmal explosion of April 5, 2003, some of the summit stations reached values above 20,000 Bq/ $\mathrm{m}^{3}$, respectively 12 and 14 days the above events. Therefore, we have indicated this value as a reference in Fig. 9. 
It can be seen that peak values in daily absolute residuals (drastically higher than $3 \sigma$ values) were obtained 14 days before the onset of the major explosion of December 6, 2008 (which is the most energetic) and one day before the lava overflow of March 29, 2009. In the first case radon concentrations reached peak values of $25,000 \mathrm{~Bq} / \mathrm{m}^{3}$ on November 22,2008 , whereas radon values dropped down to values of $\sim 6,000 \mathrm{~Bq} / \mathrm{m}^{3}$ on March 28, 2009, i.e., one day before the lava overflow. We must stress that we are analyzing two distinct volcanic processes (that, in turn, occurred under similar and moderate rainfall conditions, Fig. 8): in the first case radon showed a definite increasing trend due to higher "secondary" degassing along the fracture zone of the summit area, in the second case the most plausible explanation is that gas release was essentially concentrated within the conduit during the ascent of the degassing magma column; this would explain the drop in radon concentration just before lava effusion (this view is consistent with the relative increase in $\mathrm{CO}_{2} / \mathrm{SO}_{2}$ ratios within the plume one week before the overflow, Fig. 8). In terms of absolute residuals, both cases were characterized by marked peak values, suggesting that under critical conditions drastic variations in radon emissions were indicative of changes in the eruption style of the volcano. However, these changes should be carefully evaluated by taking into account other geochemical and geophysical parameters, as well as remote observations by means of optical and thermal cameras on the "state of the volcano".

Vent overpressure for the major explosion of May 3, 2009 was drastically lower and a precursory radon signal cannot be identified.

We also emphasize that peaks in absolute residuals, recorded from January to late February 2009, were accompanied by the extreme variability in soil temperatures, atmospheric pressure and rainfall conditions. Therefore the application of this methodology should be restricted to periods characterized by a moderate variability of environmental parameters. 


\section{Conclusions}

We have analyzed the radon signals recorded at Stromboli from May 2008 to May 2009 at two real-time stations deployed in sectors of diffuse and concentrated degassing (located onto the NE flank and summit of the volcano, respectively). Radon data together with environmental parameters (soil temperature and atmospheric pressure) were automatically transferred and plotted as time series. We found a general agreement among the trends of radon data and those of other geochemical parameters $\left(\mathrm{CO}_{2}\right.$ fluxes and the $\mathrm{CO}_{2} / \mathrm{SO}_{2}$ plume ratio) during periods of minor to moderate rainfalls. In addition, we investigated the radon signals together with those associated with the variations of environmental parameters, and found a negative correlation between radon emissions, soil temperature and atmospheric pressure. Multiple Linear Regression analysis (including the effects of tidal forces, e.g., Cigolini et al., 2009) gave us the opportunity to calculate the residuals obtained by the difference between measured and calculated radon concentrations.

By considering the time series of absolute variations of the daily radon residuals for the summit station, we suggest a methodological approach that can be used in predicting a "violent", a major explosion and/or an overflow during periods characterized by a moderate variability of environmental parameters. In summary, high radon values coupled with high radon daily residuals are indicative of significant changes in Stromboli eruptive style. The application of these methods could be regarded as a reference point in further analyzing the radon signal.

Acknowledgments. This research has benefited from funding provided by the Italian Presidenza del Consiglio dei Ministri - Dipartimento della Protezione Civile (DPC). Scientific papers funded by DPC do not represent its official opinion and policies. We thank A. Aiuppa and A. Rizzo for providing additional geochemical data. Thank to P. Poggi and C. Ciamberlini (INOA - Firenze) for their technical support on the development of the real-time stations. Thank to G. Ulivieri and D. Delledonne (University of Florence) for help in the processing data. V. Oeser of Sarad Gmbh provided technical advice. M. Neri and two anonymous referees provided helpuful comments to an earlier draft of the paper. 


\section{References}

Acocella, V., Neri, M., Walter, T.H., 2009. Structural features of Panarea volcano in the frame of the Aeolian Arc (Italy): Implications for the 2002-2003 unrest. Journal of Geodynamics, 47, 288292.

Aiuppa, A., Federico, C., Giudice, G., Giuffrida, G., Guida, R., Gurrieri, S., Liuzzo, M., Moretti, R., Papale, P., 2009. The 2007 eruption of Stromboli volcano: Insights from real-time measurement of the volcanic gas plume CO2/SO2 ratio. J. Volcanol. Geotherm. Res. 182(3-4): 221-230.

Allard P., Carbonelle J.M., Faivre-Peirret R., Martin D., Sabroux J.C., Zettwoog, P., 1991. Eruptive and diffusive emissions of CO2 from Mt. Etna. Nature 351: 387-391.

Allard, P., Aiuppa, A., Burton, M., Caltabiano, T., Federico, C., Salerno, G., La Spina, A., 2008. Crater gas emissions and the magma feeding system of Stromboli volcano. In: The Stromboli volcano: an integrated study of the 2002-2003 eruption (eds. Calvari S. et al.). AGU Geophysical Monograph Series, 182, 19-37.

Alparone, S., Behncke, B. , Giammanco, S., Neri, M., Privitera, E., 2005. Paroxysmal summit activity at Mt. Etna (Italy) monitored through continuous soil radon measurement. Geoph. Res. Lett. 2: L16307, doi:10.1029/2005GL023352.

Barberi, F., Rosi, M., Sodi, A., 1993. Volcanic hazard assessment at Stromboli based on review of historical data. Acta Vulcanol. 3: 173-187. 
Barberi, F., Civetta, L., Rosi, M., Scandone, R., 2008. Chronology of the 2007 eruption of Stromboli and the activity of the Scientific Synthesis Group. J. Volcanol. Geotherm. Res. 182(3-4): 123-130.

Barnet, I., Prochazka, J., Skalsky, L., 1997. Do the earth tides have an influence on short-term variations in radon concentration? Rad. Prot. Dosimetry 69: 51-60.

Bonaccorso, A., Calvari, S., Garfi, G., Lodato, L., Patanè, D., 2003. Dynamics of the December 2002 flank failure and tsunami at Stromboli volcano inferred by volcanological and geophysical observations. Geoph. Res. Lett. 30 (23): 2214, doi:10.1029/2003GL0188961941

Bonetti, R., Capra, L. , Chiesa, C. , Guglielmetti, A., Migliorini, C., 1991. Energy response of LR115 cellulose nitrate to $\alpha$-particle beams. Nucl. Rad. Measur. 18: 321-338.

Burton, M., Neri, M., Condarelli, D., 2004. High spatial resolution radon measurements reveal hidden active faults on Mt. Etna. Geoph. Res. Lett. 31: L07618.

Calvari, S., Spampinato, L., Lodato., S., Harris, A.J., Patrick, M.R., Dehn, J., Burton, M., Andronico, D., 2005. Chronology and complex volcanic processes during the 2002-2003 flank eruption at Stromboli volcano (Italy) reconstructed from direct observations and surveys with a handheld thermal camera. J. Geophys. Res. 110: B02201, doi:10.1029/2004JB003129.

Carapezza, M.L., Inguaggiato, S., Brusca, L., Longo, M., 2004. Geochemical precursors of Stromboli 2002-2003 eruptive events. Geophys. Res. Lett. 31-7. doi:10.1029/2004GL019614. 
Carapezza, M.L., Ricci, T., Ranaldi, M., Tarchini, L. 2008. Active degassing structures of Stromboli and variations in diffuse $\mathrm{CO}_{2}$ output related to the volcanic activity. J. Volcanol. Geotherm. Res. 182 (3-4): 231-245.

Chirkov, A.M. 1975. Radon as a possible criterion for predicting eruptions as observed at Karymsky volcano. Bull. Volcanol. 39: 126-131.

Cigolini, C., Laiolo, M., Coppola, D., 2007. Earthquake-volcano interactions detected from radon degassing at Stromboli (Italy). Earth Planet. Sci. Lett. 257: 511-525.

Cigolini, C., Salierno, G., Gervino, G., Bergese, P., Marino, C., Russo, M., Prati, P., Ariola, V., Bonetti, R., Begnini, S., 2001. High-resolution Radon Monitoring and Hydrodynamics at Mount Vesuvius. Geoph. Res. Lett. 28 (21): 4035-4039.

Cigolini, C., Gervino, G., Bonetti, R., Conte, F., Laiolo, M., Coppola, D., Manzoni, A. , 2005. Tracking precursors and degassing by radon monitoring during major eruptions at Stromboli Volcano (Aeolian Islands, Italy), Geophys. Res. Lett. 32: L12308, doi:10.1029/2005GL022606.

Cigolini, C., Poggi, P., Ripepe, M., Laiolo, M., Ciamberlini, C., Delle Donne, D., Ulivieri, G., Coppola, D., Lacanna, G., Marchetti, E., Piscopo, D., Genco, R., 2009. Radon surveys and real-time monitoring at Stromboli volcano: influence of soil temperature, atmospheric pressure and tidal forces on ${ }^{222} \mathrm{Rn}$ degassing. J. Volcanol. Geotherm. Res. 184(3-4): 381-388.

Cigolini, C., 2010. The dynamics of a double-cell hydrothermal system in triggering seismicity at Somma-Vesuvius: results from a high-resolution radon survey (revisited). Bull. Volcanol. 72: 693704. 
Connors, C., Hill, B., La Femina, P., Navarro, M., Conway, M., 1996. Soil Rn-222 pulse during the initial phase of the June August 1995 eruption of Cerro Negro, Nicaragua. J. Volcanol. Geothermal Res. 73: 119-127.

Cox, M.E., 1980. Ground Radon Survey of a Geothermal area in Hawaii. Geoph. Res. Lett. 7: 283286.

De Astis, G., Ventura, G., Vilardo, G., 2003. Geodynamic significance of the Aeolian volcanism (Southern Tyrrhenian Sea, Italy) in light of structural, seismological, and geochemical data, Tectonics. 22/4, art. n. 1040/14.

Finizola, A., Sortino, F., Lenat, J.F., Valenza, M., 2002. Fluid circulation at Stromboli volcano (Aeolian Islands, Italy) from self-potential and CO2 surveys. J. Volcanol. Geoth. Res. 116: 1-18.

Finizola, A., Sortino F.,Lénat, J.F., Aubert, M., Ripepe M., Valenza, M., 2003. The summit hydrothermal system of Stromboli. New insights from self-potential, temperature, $\mathrm{CO} 2$ and fumarolic fluid measurements, with structural and monitoring implications. Bull. Volcanol. 65: 486-504, doi:10.1007/s00445-003-0276-Z.

Fleischer, R. L., Mogro-Campero, A., 1985. Association with subsurface radon changes in Alaska and the Northeastern United States with earthquakes. Geochim. Cosmochim. Acta, 49: 1061-1071.

Gauthier, P.J., Condomines, C. 1999. ${ }^{210} \mathrm{~Pb}^{-26} \mathrm{Ra}$ radioactive disequilibria in recent lavas and radon deggassing : inferences on the magma chamber dynamics at Stromboli and Merapi volcanoes. Earth Planet. Sci. Lett. 172: 111-126. 
Giammanco, S., Sims, K. W. W. , Neri, M., 2007. Measurements of 220Rn and 222Rn and CO2 emissions in soil and fumarole gases on Mt. Etna volcano (Italy): Implications for gas transport and shallow ground fracture. Geochem. Geophys. Geosyst. 8: Q10001, doi:10.1029/2007GC001644.

Giammanco, S., Immè, G., Mangano, G., Morelli, D., Neri, M., 2009. Comparison between different methodologies for detecting Radon in soil along an active fault: the case of the Pernicana fault system, Mt. Etna. Applied Radiation and Isotopes 67(1): 178-185, doi:10.1016/j.apradiso.2008.09.007.

Gillot, P.Y., Keller, J., 1993. Radiochronological dating of Stromboli. Acta Vulcanol. 3: 69-77.

Hornig-Kjarsgaard, I., Keller, J., Koberski, U., Stadbauer, E., Francalanci, L., Lenhart, R., 1993. Geology, stratigraphy and volcanological evolution of the island of Stromboli, Aeolian arc, Italy. Acta Vulcanol. 3: 21-68.

Gründel, M., Postendörfer. J., 2003. Characterization of an electronic Radon gas personal Dosimeter. Radiation Protection Dosimetry 107 No. 4: 287-292.

Harris, A.J.L., Ripepe, M., 2007. Temperature and Dynamics of Degassing at Stromboli. J. Geophys. Res. 112: doi:1029/2006JB0004393.

Hernandez, P., Perez, N., Salazar, J., Reimer, M., Notsu, K., Wakita, H. 2004. Radon and helium in soil gases at Cañadas caldera, Tenerife, Canary Islands, Spain. J. Volcanol. Geotherm. Res. 131: 5976. 
Igarashi, G., Saeki, S., Takahata, N., Sumikawa, K., Tasaka, S., Sasaki, Y., Takahashi, M., Sano, Y., 1995. Ground-water Radon Anomaly before the Kobe Earthquake in Japan. Science 269: 60-61.

Kotrappa, P., Dempsey, J.C., Stieff, L.R., 1993. Recent advances in electret ion chamber technology. Rad. Prot. Dosim. 47: 461-464.

Mogro-Campero, A., Fleischer, R. L., 1977. Subterrestrial fluid convection: a hypothesis for long distance migration of radon within the earth. Earth Planet. Sci. Lett. 34: 321-325.

Nazaroff, W.W., 1992. Radon transport from soil to air. Reviews of Geophysics 30: 137-160, doi: 92RG00055.

Neri, M., Behncke, B., Burton, M., Giammanco, S., Pecora, E., Privitera, E., Reitano, D., 2006a. Continuous soil radon monitoring during the July 2006 Etna eruption. Geophys. Res. Lett. 33: L24316, doi:10.1029/2006GL028394.

Neri, M., Lanzafame, G., 2008. Structural features of the 2007 Stromboli eruption. J. Volcanol. Geoth. Res. 182(3-4): 137-144.

Ouzounov, D., Freund, F.T., 2004. Mid-infrared emission prior to strong earthquakes analyzed by remote sensing data. Advanc. Space Res. 33: 268-273.

Pérez, N.M., Hernández, P.A., Padrón, E., Melián, G., Marrero, R., Padilla, G., Barrancos, J., Nolasco, D., 2007. Precursory subsurface ${ }^{222} \mathrm{Rn}$ and ${ }^{220} \mathrm{Rn}$ degassing signatures of the 2004 seismic crisis at Tenerife, Canary Islands. Pure Appl. Geophys. 164: 2431-:2448. 
Perrier, F., Richon, P., Sabroux, J., 2009. Temporal variations of radon concentration in the saturated soil of Alpine grassland: the role of groundwater flow. Sci. Tot. Environm. 407: 23612371.

Planicić, J., Radolić, V., Vuković, B., 2004. Radon as an earthquake precursor. Nucl. Instr. Meth. in Phys. Res. S. A 530: 568-574.

Pulinets, S A; Ouzounov, D P; Giuliani, G G, Ciraolo, L., Taylor, P.T., 2009. Atmosphere and radon activities observed prior to Abruzzo M6.3 earthquake of April 6, 2009. Eos Trans. AGU 90(52): Abstract AN: U14A-07.

Ripepe, M., Marchetti, E., Ulivieri, G., Harris, A.J., Dehn, J., Burton, M., Caltabiano, T., Salerno, G., 2005. Effusive to explosive transition during the 2003 eruption of Stromboli volcano. Geology 33/5: 341-344.

Ripepe, M., Marchetti, E.; Ulivieri, G., 2007. Infrasonic monitoring at Stromboli volcano during the 2003 effusive eruption: Insights on the explosive and degassing process of an open conduit system. J. Geophys. Res., 112, B09207: 13 pp., doi:10.1029/2006JB004613.

Rizzo, A., Grassa, F., Inguaggiato, S., Liotta, M., Longo, M., Madonia, P., Brusca, L., Capasso, G., Moricia, S., Rouwet, D., Vita, F., 2009. Geochemical evaluation of observed changes in volcanic activity during the 2007 eruption at Stromboli (Italy). J. Volcanol. Geotherm. Res. 182 (3-4): 246254.

Rosi, M., Bertagnini, A., Landi, P., 2000. Onset of persisting activity at Stromboli Volcano (Italy). Bull. Volcanol. 62: 294-300. 
Scholtz, C.H., Sykes, L.R., Aggarval, Y.P., 1973. Earthquake prediction: a physical basis. Science 181: 803-810.

Siniscalchi, A., Tripaldi, S., Neri, M., Giammanco, S., Piscitelli, S., Balasco, M., Behncke, B., Magrì, C., Naudet, V., Rizzo, E., 2010. Insights into fluid circulation across the Pernicana Fault (Mt. Etna, Italy) and implications for flank instability. J. Volcanol. Geotherm. Res. 193: 137-142, doi:10.1016/j.jvolgeores.2010.03.013.

Streil, T., Oeser, V., Feige, S., 2002. An electronic radon dosimeter as a multipurpose device-a bridge between dosimetry and monitoring. Geofisica Internacional 41: 285-288.

Su, C.C., Huh, C.A., 2002. Atmospheric Po-210 anomaly as a precursor of volcano eruptions. Geophys. Res. Lett. 29(5): doi 2001GL013856.

Thomas, D.M., Cox, M.E., Cuff, K.E., 1986. The association between ground gas radon variations and geologic activity in Hawaii. J. Geophys. Res. 91: 12186-12198.

Tibaldi, A., 2001. Multiple sector collapses at Stromboli volcano, Italy: how they work. Bull. Volcanol. 63: 112-125, doi:10.1007/s004450100129.

Tibaldi, A., Corazzato, C., Marani, M., Gamberi, F., 2009. Subaerial-submarine evidence of structures feeding magma to Stromboli Volcano, Italy, and relations with edifice flank failure and creep. Tectonophysics 469: 112-136.

Varley, N.R., Armienta, M.A., 2001. The absence of diffuse degassing at Popocatepetl volcano, Mexico. Chem. Geol. 177: 157-173. 
Viveiros, F., Ferreira, T., Cabral Vieira, J., Silva, C., Gaspar, J.L., 2008. Environmental influences on soil $\mathrm{CO}_{2}$ degassing at Furnas and Fogo volcanoes (São Miguel Island, Azores archipelago). J. Volcanol. Geotherm. Res. 177(4): 883-893.

Wakita, H., 1996. Geochemical challenge to earthquake prediction. Proc. Natl. Acad. Sci. USA 93: 3781-3786.

Williams-Jones, G., Stix, J., Heiligmann, M., Charland, A., Sherwood Lollar, B., Arner, N., Garzón, G.V., Barquero, J., Fernandez, E., 2000. A model of diffuse degassing at three subduction-related volcanoes. Bull. Volcanol. 62: 130-142.

Wyss, M., 1991. Evaluation of Proposed Earthquake Precursors (ed. M. Wyss). AGU, Washington, DC 1991: 94 pp.

Wyss, M., 1997. Second round of evaluations of earthquake precursors. Pure Appl. Geophys., 149: 3-16.

Zimmer, M., Erzinger, J., 2003. Continuous H2O, CO2, 222Rn and temperature measurements on Merapi Volcano,Indonesia, J. Volcanol. Geoth. Res. 125: 25-38.

\section{Figure Captions}

Figure 1. a) Simplified geological map of Stromboli with major collapses and faults (modified after Tibaldi et al., 2009) and location of the two real-time stations (LSC and PZZ); inset shows the 
structural setting of the southern Tyrrhenian region; b) topographic DEM image of the summit area with the locations of active fumaroles (modified after Finizola et al., 2002).

Figure 2. Total daily decays count computed by the two DOSEMan alpha-spectrometers (SARAD Gmbh) of the ${ }^{222} \mathrm{Rn}$ monitoring stations; see text for details.

Spectral distribution of the different isotopes of the radon progeny detected by DOSEman (subdivided into Region of Interest, ROIs) for both the real-time stations operative at Stromboli.

Figure 3. Time series of ${ }^{222} \mathrm{Rn}$ concentration at the Liscione station (LSC) displayed with soil temperature and atmospheric pressure. The black curve refers to average daily concentrations, grey circles represent 4 hour average values.

Figure 4. Time series of ${ }^{222} \mathrm{Rn}$ concentration at the Pizzo station (PZZ) displayed with soil temperature and atmospheric pressure. The black curve refers to average daily concentrations, grey circles represent 4 hour average values.

Figure 5. Cross-correlation for soil temperature versus ${ }^{222} \mathrm{Rn}$ concentrations (daily average values) for the data collected at LSC and PZZ real-time stations, respectively.

Figure 6. Summary of the observed ${ }^{222} \mathrm{Rn}$ time series measured at LSC station compared with calculated radon values (black curve) obtained by Multiple Linear Regression. Residuals are shown separately.

Figure 7. Summary of the observed ${ }^{222} \mathrm{Rn}$ time series measured at summit PZZ station compared with calculated radon values (black curve) obtained by Multiple Linear Regression. Residuals are shown separately. 
Figure 8. Time-series of the observed ${ }^{222} \mathrm{Rn}$ concentrations, reported as weekly average concentrations compared with weekly average soil $\mathrm{CO}_{2}$ flux and plume $\mathrm{CO}_{2} / \mathrm{SO}_{2}$ ratios. The latter data are from the weekly reports provided by INGV (cf., http://www.pa.ingv.it/comunicati/Stromboli/comunicati_stromboli.php). The cumulate curve for regional rainfalls (in $\mathrm{mm}$ ) has been obtained from the data of the Messina station (Servizio Metereologico dell'Aeronautica). Black bars are the major explosions and dotted bar represent the lava overflow. From May 2008 to mid-January 2009 the $\mathrm{Rn}-\mathrm{CO}_{2}$ correlation coefficient is 0.52 , since then it becomes slightly anti-correlated. Similar results are also found for $\mathrm{Rn}-\mathrm{CO}_{2} / \mathrm{SO}_{2}$ data.

Figure 9. Raw data of daily radon concentrations and relationships between absolute daily variations (gradient) computed for the residuals of the PZZ station, and the onset of significative volcanic events during our year-long monitoring at Stromboli volcano. (see text for details). 
Figure 1
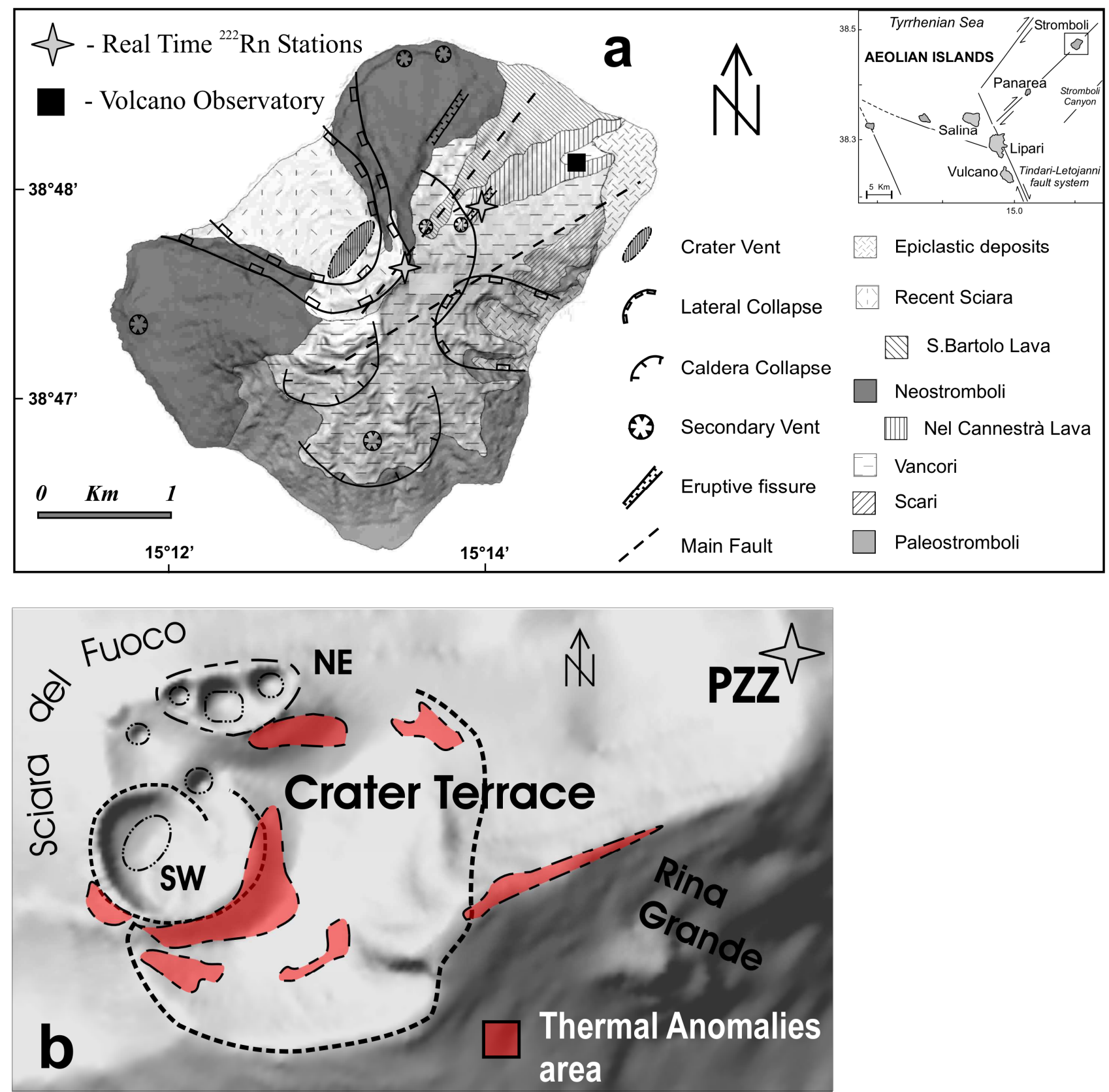
Figure 2

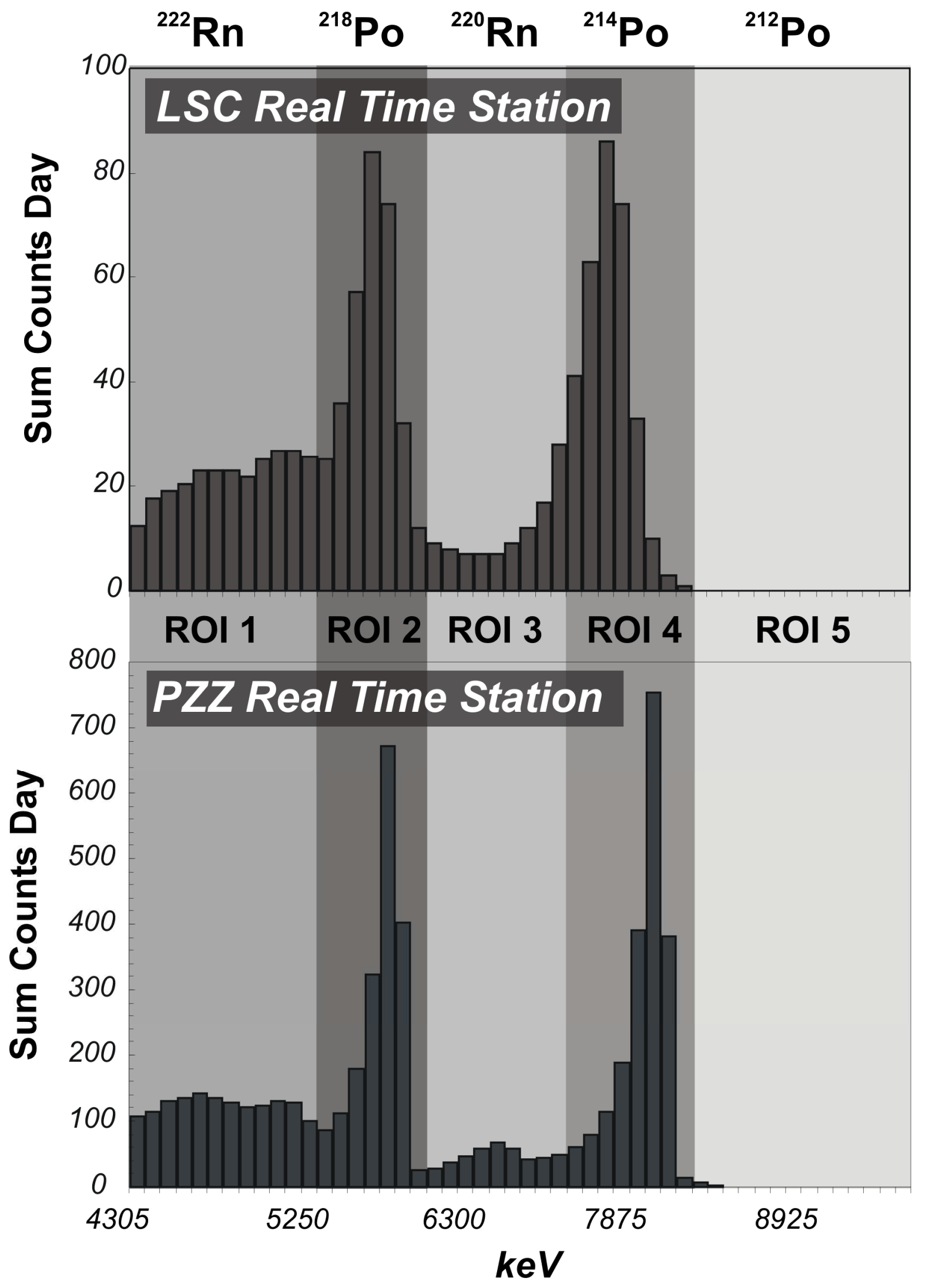


Figure 3
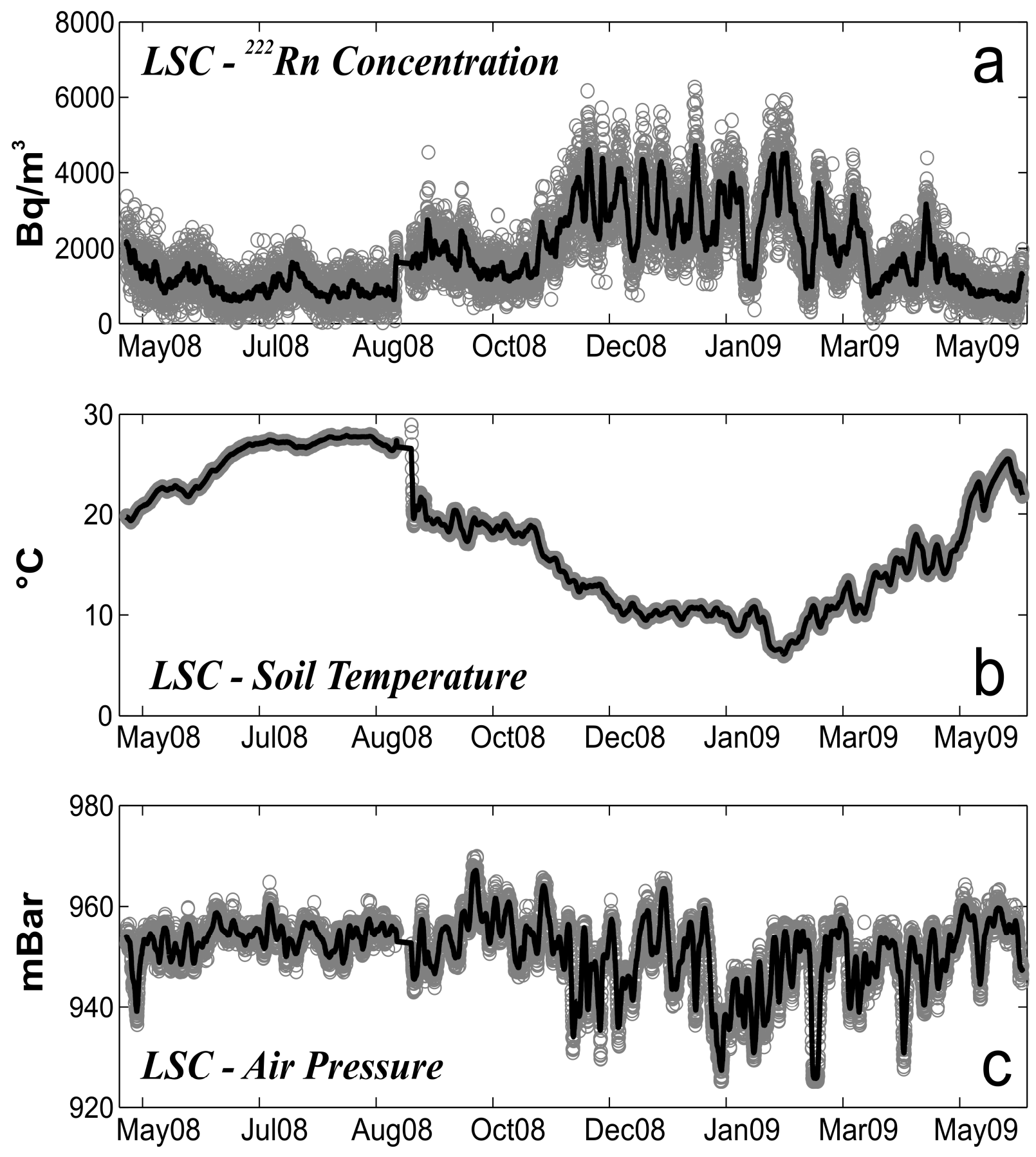
Figure 4
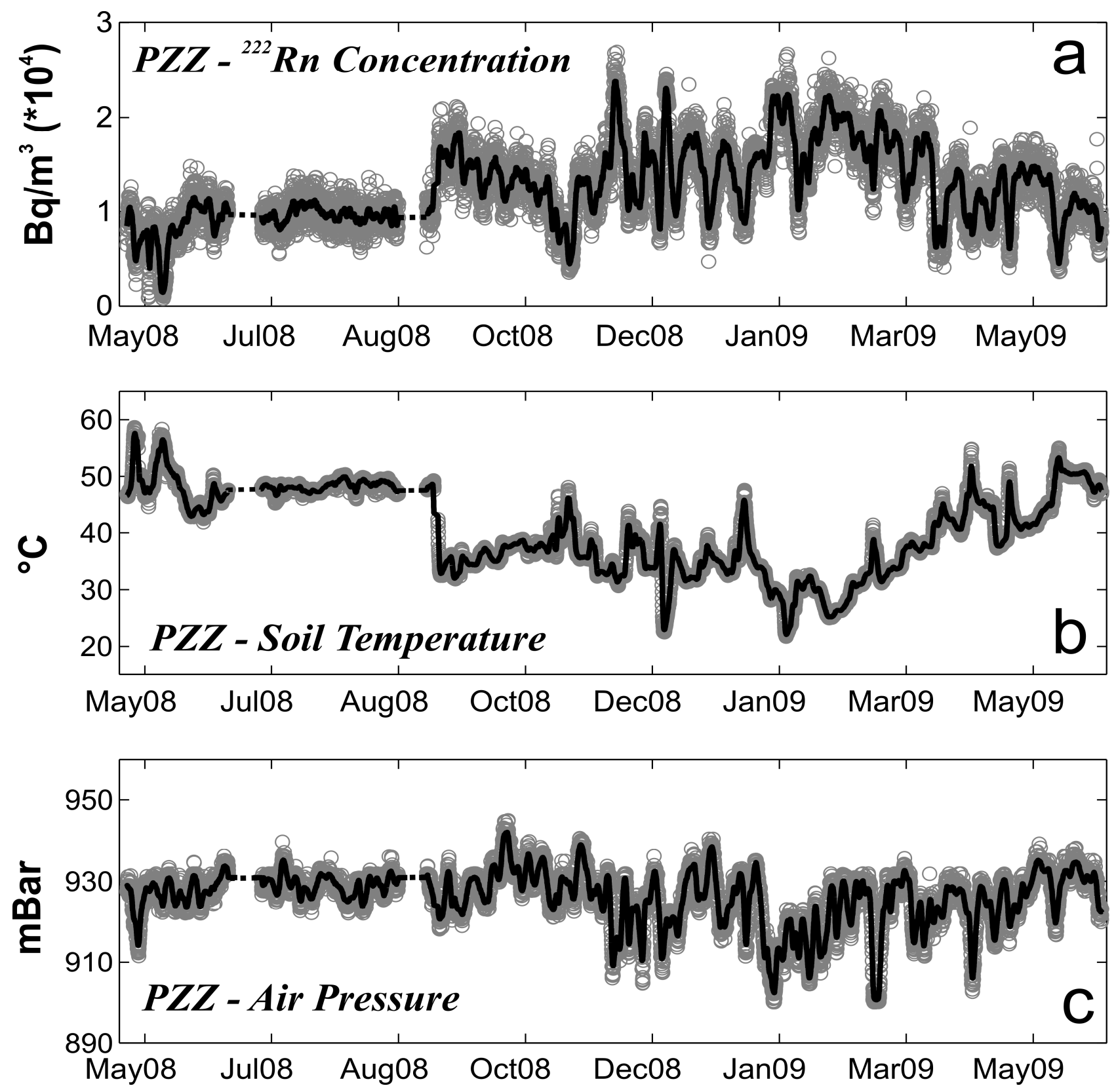
Figure 5
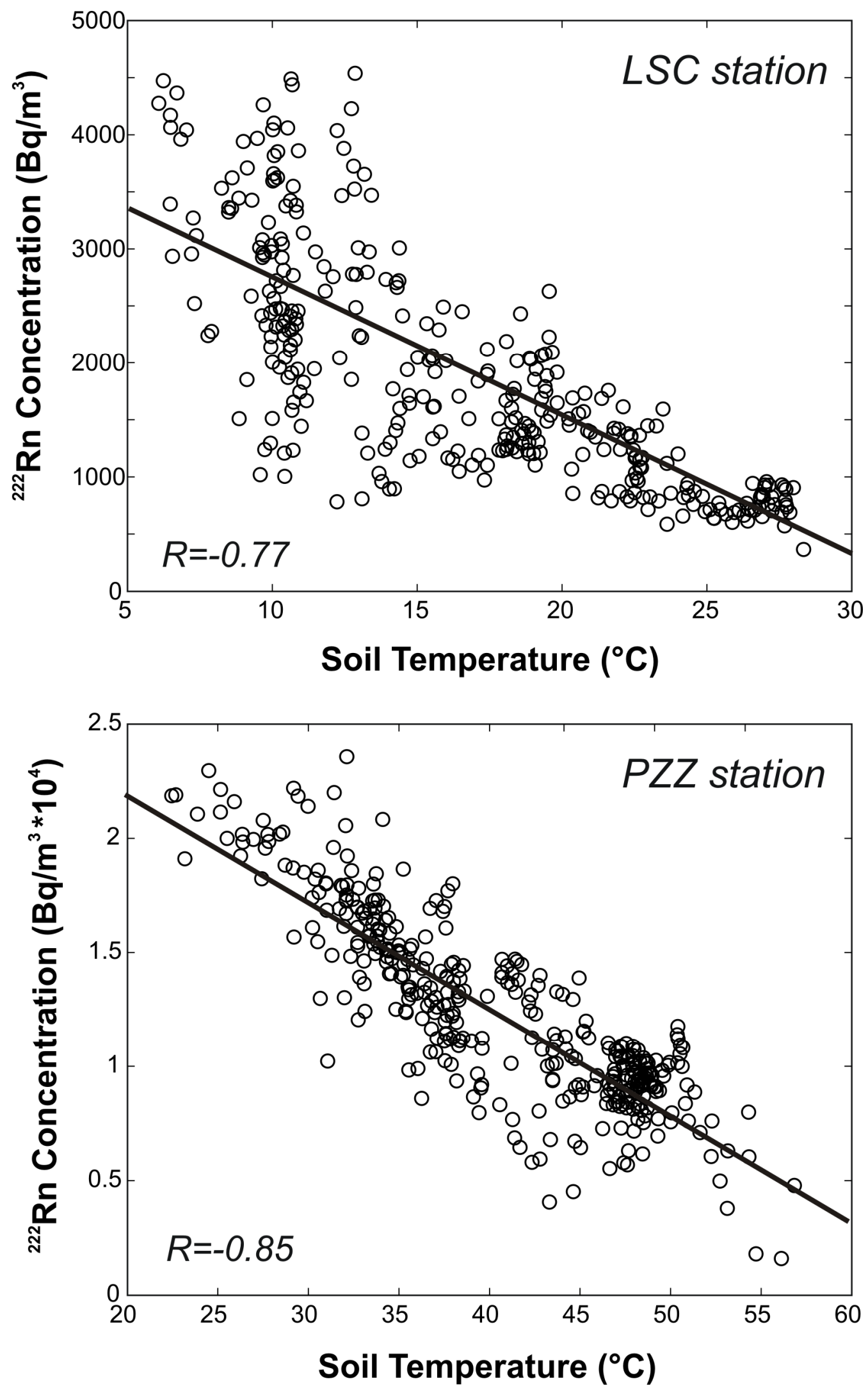
Figure 6

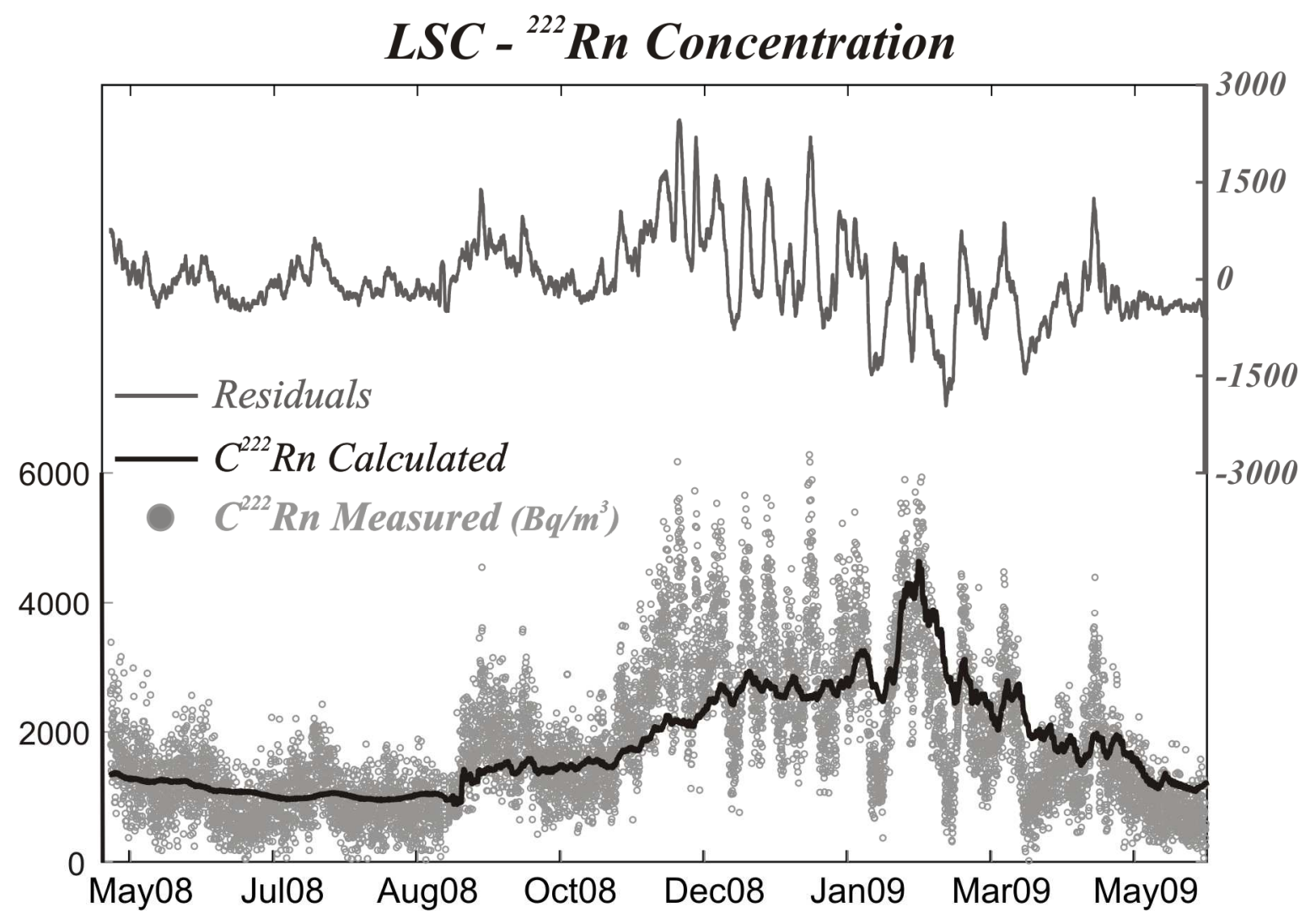

Figure 7

$P Z Z-{ }^{222} R n$ Concentration

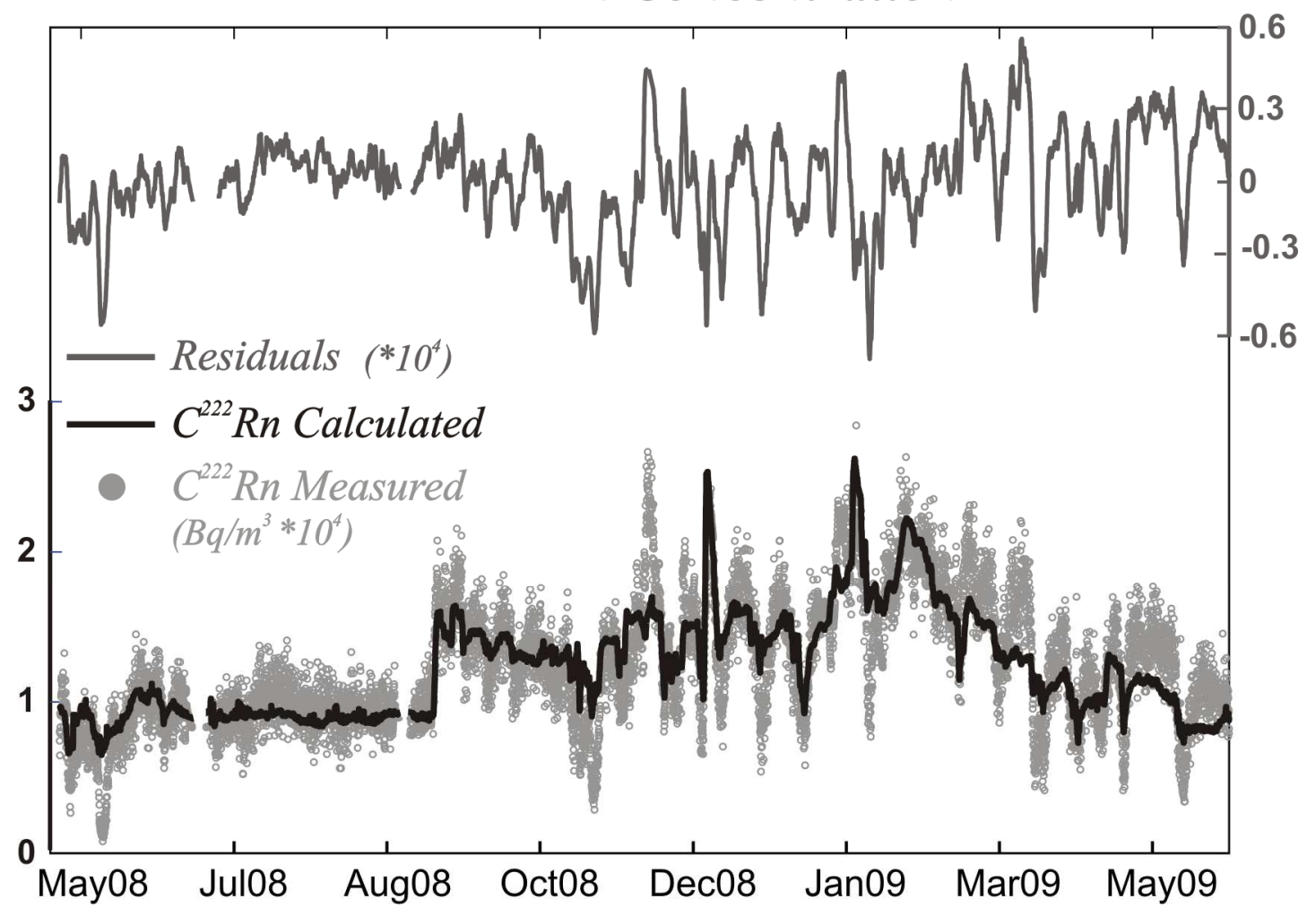


Figure 8
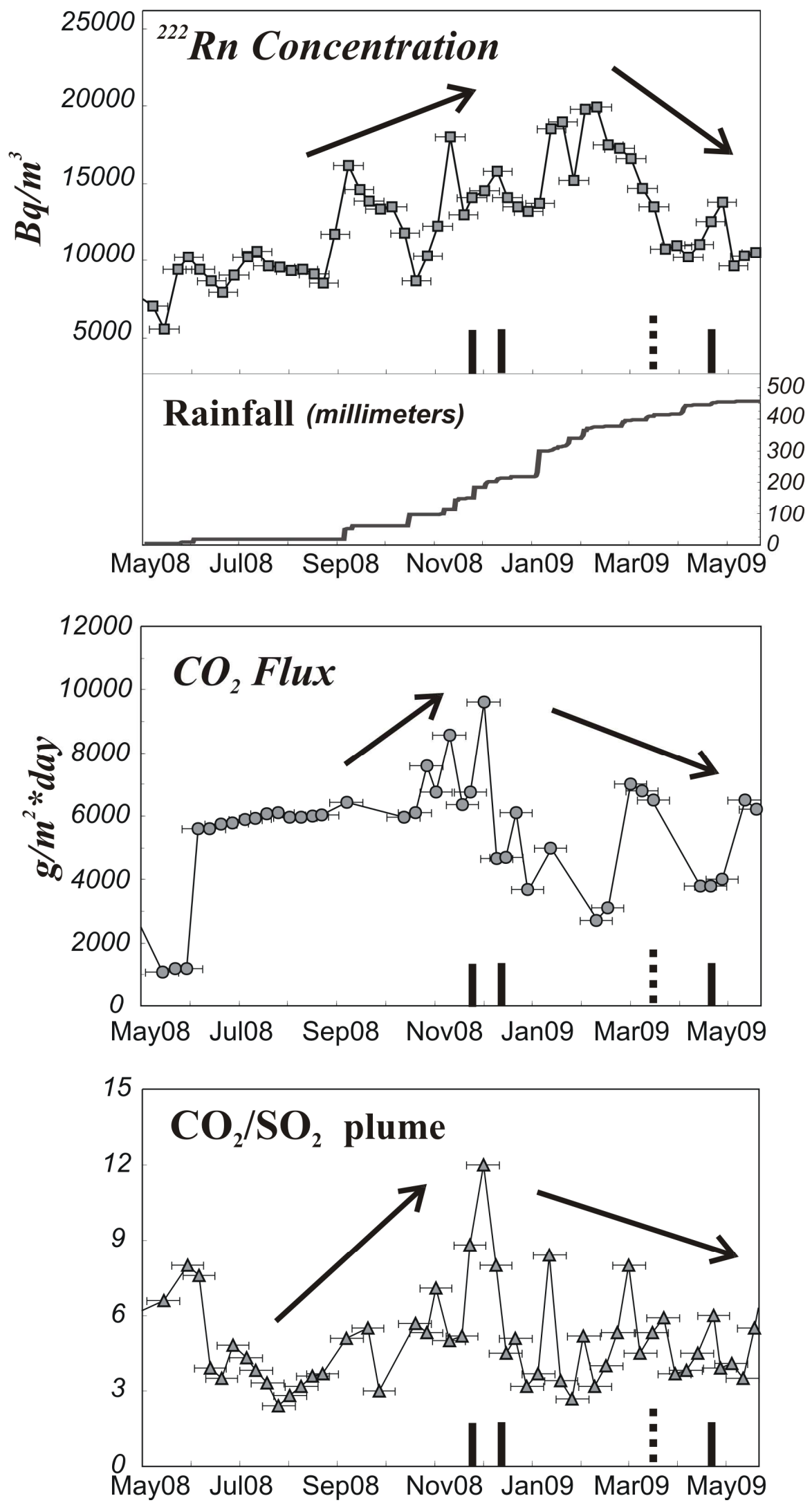
Figure 9

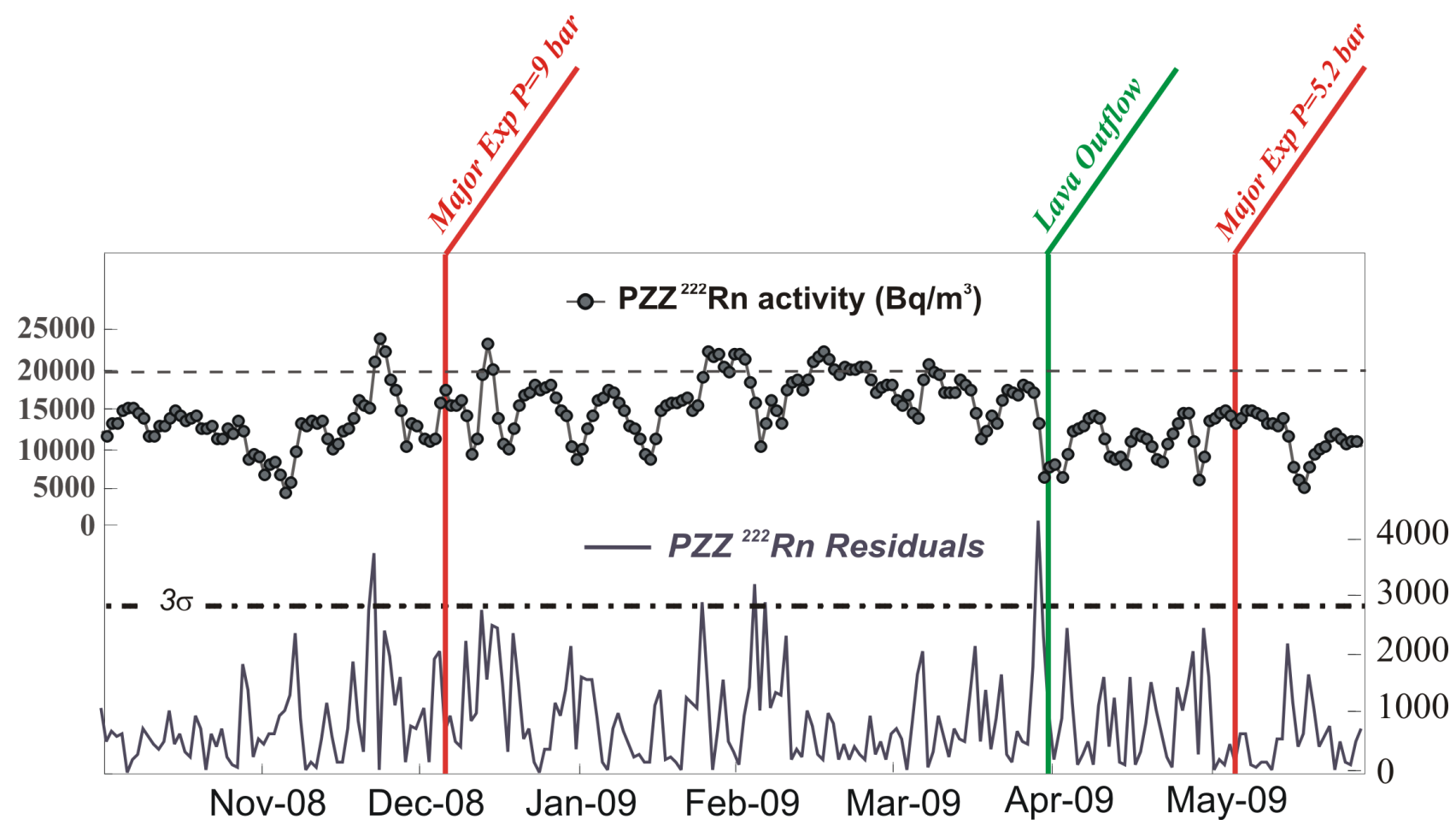

Table 1 - Daily average of the total counts recorded in the main Region Of Interest (ROI) by means of the DOSEMan Spectrometer (SARAD Gmbh) at the two recording sites at Stromboli volcano. Calibration factors depend to the volume of the detection chamber, see text for details.

\begin{tabular}{rrrrrrr}
\hline & ROI 1 & ROI 2 & ROI 3 & \multicolumn{2}{c}{ ROI 4 } & \multicolumn{2}{c}{ Calibration Factors } \\
& ${ }^{222} \mathrm{Rn}$ & ${ }^{218} \mathrm{PO}$ & ${ }^{220} \mathrm{Rn}$ & ${ }^{214} \mathrm{Po}$ & Fast & Slow \\
LSC Station & 181 & 199 & 41 & 276 & 0.22 & 0.32 \\
PZZ Station & 827 & 1140 & 181 & 1299 & 0.19 & 0.32 \\
\hline
\end{tabular}




\section{Table 2}

Mean, standard deviation and correlations between ${ }^{222} \mathrm{Rn}$ concentration and the environmental parameters acquired by the real-time stations operating at Stromboli

\begin{tabular}{|c|c|c|c|c|c|}
\hline & Mean & $S D^{a}$ & $\begin{array}{c}{ }^{222} R n \\
\left(B q / m^{3}\right)\end{array}$ & $\begin{array}{l}\text { Air } P \\
\text { (mBar) }\end{array}$ & $\begin{array}{l}\text { Soil } T \\
\left({ }^{\circ} \mathrm{C}\right)\end{array}$ \\
\hline \multicolumn{6}{|l|}{ LSC station } \\
\hline${ }^{222} R n\left(B q / m^{3}\right)$ & 1797.09 & 977.38 & 1.00 & -0.42 & -0.77 \\
\hline Air $P$ (mBar) & 950.87 & 5.92 & -0.42 & 1.00 & 0.47 \\
\hline Soil $T\left({ }^{\circ} \mathrm{C}\right)$ & 17.55 & 6.09 & -0.77 & 0.47 & 1.00 \\
\hline \multicolumn{6}{|l|}{ PZZ station } \\
\hline${ }^{222} R n\left(B q / m^{3}\right)$ & 12573.81 & 4187.78 & 1.00 & -0.34 & -0.85 \\
\hline Air $P$ (mBar) & 928.35 & 6.84 & -0.34 & 1.00 & 0.35 \\
\hline Soil $T\left({ }^{\circ} \mathrm{C}\right)$ & 39.98 & 7.31 & -0.85 & 0.35 & 1.00 \\
\hline
\end{tabular}

a - SD: standard deviation 